\title{
Witnesses to the truth: Mark's point of view
}

\section{Authors:}

Deven K. MacDonald ${ }^{1}$

Ernest Van Eck ${ }^{1}$

\section{Affiliations:}

${ }^{1}$ Department of New

Testament Studies, University

of Pretoria, South Africa

Project Leader: E. van Eck

Project Number: 2400030

\section{Description:}

This research is part of the project, 'Socio-Cultural

Readings', directed by Prof.

Dr Ernest van Eck, Department

of New Testament Studies,

Faculty of Theology, University

of Pretoria.

\section{Corresponding author:}

Ernest Van Eck,

ernest.vaneck@up.ac.za

Dates:

Received: 03 Feb. 2016

Accepted: 29 Mar. 2016

Published: 12 Aug. 2016

How to cite this article: MacDonald, D.K. \& Van Eck, E., 2016, 'Witnesses to the truth: Mark's point of view', HTS Teologiese Studies/ Theological Studies 72(1), a3350, x pages. http://dx.do org/10.1402/hts.v72i1.3350

\section{Copyright:}

(C) 2016. The Authors. Licensee: AOSIS. This work is licensed under the Creative Commons Attribution License.

\section{Read online:}

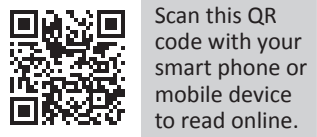

This article presents a narratological reading of the Gospel of Mark with special attention given to the role, function and rhetorical impact of point of view. It is argued that through the use of 'witnesses' ranging from the omniscient narrator, to the character God, to the Old Testament Scriptures, the author of Mark presents a point of view that his implied reader would find difficult to counter. In addition to this, the article demonstrates that the motifs of allegiance, misunderstanding and opposition in the Second Gospel are almost entirely confined to the adoption or rejection of the point of view being advocated for by the author of Mark. In the end, it is shown that only in the death of Jesus on the cross and the subsequent 'centurion's confession' are the motifs resolved and is the point of view of Mark accepted by a human character.

\section{Introduction}

There are two almost inseparable questions the narrative critic asks of a text: What does the story mean; and, how does the story mean? Answering this involves understanding the role of narrator, the function and concept of intended and implied audience, and sensitivity to the development and narratival significance of point of view. For example, how does this omniscient narrator anticipate his audience to respond to the narrative world and events that he offers them? Or, to put it another way, how would the implied reader be expected to respond to the text? To answer these questions, the final text must serve as guide. The most logical manner in which to locate the implied reader is to look at the story the narrator has left. Obviously, there are an infinite number of possible readers, but the most probable one is the one that the text anticipates. ${ }^{1}$

This article examines the nature of the point of view being presented in Mark's gospel, and argues that the narrator recruits 'witnesses' to reinforce his point of view and ensure that the implied reader adopts his view point. ${ }^{2}$ It is argued that central to Mark's point of view is the belief that Jesus is the Son of God, and that to respond to that reality favourably constitutes allegiance. Furthermore, it is noted that the motifs of misunderstanding and opposition are portrayed as stemming from a failure to accept the narrator's point of view and recognise Jesus' divine sonship. ${ }^{3}$

\section{Mark 1:1-11: The development of point of view}

The relationship of point of view and the experience of a reader is explained by Resseguie: 'In apprehending narrative point of view, the reader discovers the norms, values, beliefs and general worldview that the narrator wants the reader to adopt or reject' (Resseguie 2005:167). ${ }^{4}$

The narrator of Mark begins his gospel with startling words: 'The beginning of the gospel of Jesus Christ Son of God' (Mk 1:1; ESV). The textual variant that underlies 1:1 is a significant one. ${ }^{5}$ After

1.For a definition of 'implied reader', and what exactly this means in relation to a narrative world, see Booth (1983:xiii). For an explanation of the implied reader as it relates to Mark, see Fowler (1991:61). Resseguie is correct in noting that, in addition to the significance that an omniscient narrator has in creating a narrative to be trusted, the conceptual world which he creates is equally important. More than just conveying that the narrator knows everything, and thus can be trusted, Biblical narrative (especially the Gospels) creates an ideological point of view in which the 'objective' point of view (of the omniscient narrator) and a 'subjective' point of view (understood as ideological point of view) to get its point across (Resseguie 2005:169).

2.This article represents a reworked version of aspects from the PhD dissertation of Deven K. MacDonald, titled Allegiance, opposition and misunderstanding: A narrative critical approach to 'Son of God' in Mark's Gospel, in the Department of New Testament Studies, University of Pretoria, with Prof. Dr. Ernest van Eck as supervisor.

3.Mark's rhetoric, though direct, is compellingly communicated through his narrative (Rhoads, Dewey \& Michie 1999:7).

4.Resseguie goes even further than this and attempts to deal with some of the ambiguity that surrounds the term 'point of view'. He offers four 'planes' of point of view and explains them well (Resseguie 2005:169-173).

5.In the 4th edition of the United Bible Societies' Greek New Testament (1994), the final two words 'Son of God' appear in brackets. This is also the case with Nestle-Aland's Novum Testamentum Graece (2012). They have given it a grade of ' $C$ ' in the textual apparatus, believing it is unlikely that it is original. The SBLGNT (2010) omits the words from their edition of the Greek text of Mark. Generally

Note: This article represents a reworked version of aspects from the PhD dissertation of Deven K. MacDonald, titled, 'Allegiance, opposition and misunderstanding: A narrative critical approach to "Son of God" in Mark's Gospel', completed under the supervision of Prof. Dr Ernest van Eck, Department of New Testament Studies, University of Pretoria, South Africa 
the evidence is considered, it appears to maintain its inclusion is wisest and thus, 'Son of God' in Mark 1:1 will be taken as original. This is not a normal proclamation or drama of little consequence. Instead, it is the 'beginning' or dawning of the good news (cf. Evans 2000:71; Van Eck 2013:6). Right from the beginning, the author ensures that the reader is clear on the true identity of who this 'Jesus' is. He is Israel's Messiah and the Son of God. What this means, however, is yet to be seen. Whatever occurs in the narrative world of Mark's gospel, whatever twists and turns the story takes, the reader is assured of this one over-arching truth; what they have before them (or, more likely being read to them) is the beginning of the gospel of Jesus Christ, God's Son. It is as if the author is saying to his audience, 'no matter what happens to Jesus, this narrative is good news! It has a happy ending!'

In addition to the pronouncement of Mark 1:1, the implied author links the good news of God's Son to Jewish eschatological hope. He 'tells' that the proper context for understanding Jesus' identity is the Old Testament (Mk 1:2-4). Additionally, he uses the primary character in his opening scene, John the Baptist, to bolster his authoritative claim that 'good news' is about to come because Jesus (it is assumed) is going to 'baptise with the Holy Spirit' (Mk 1:8). The implications of this are settled almost immediately in the next verses. Jesus is baptised by John in the Jordan and 'immediately' he saw 'heaven being torn open and the Spirit descending on him like a dove' (Mk 1:10). A voice from heaven proclaims: 'You are my beloved Son; with you I am well pleased' (Mk 1:11). The voice is understood by the reader and/or hearer to be God himself.

Here, in only a few verses, the narrator has done some significant work in aligning the reader to his point of view. ${ }^{6}$ Because the voice from heaven addressed Jesus directly, Mark, in recording it and offering it to his readers, demonstrated his own omniscience of the events at hand. $\mathrm{He}$ is, in the classic sense, the omniscient narrator (Resseguie 2005:168). The narrator begins by 'telling' (Mk 1:1), then 'shows' (Mk 1:2-4 through prophetic and eschatological

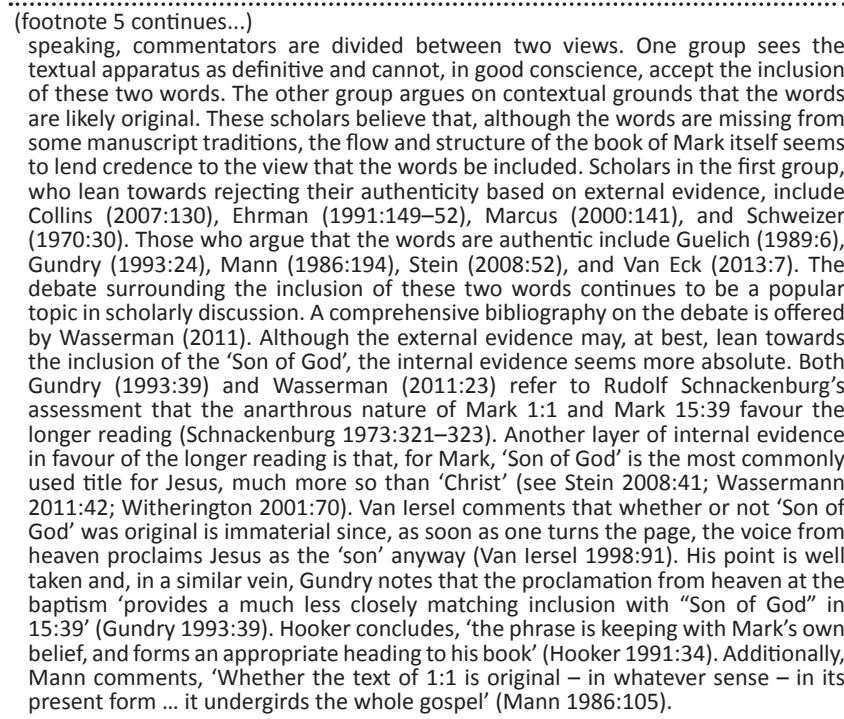
textual apparatus as definitive and cannot, in good conscience, accept the inclusion of these two words. The other group argues on contextual grounds that the words are likely original. These scholars believe that, although the words are missing from some manuscript traditions, the flow and structure of the book of Mark itself seem to lend credence to the view that the words be included. Scholars in the first group, who lean towards rejecting their authenticity based on external evidence, include Collins (2007:130), Ehrman (1991:149-52), Marcus (2000:141), and Schweize (1970:30). Those who argue that the words are authentic include Guelich (1989:6) Gundry (1993:24), Mann (1986:194), Stein (2008:52), and Van Eck (2013:7). The Gundry (1993:24), Mann (1986:194), Stein (2008:52), and Van Eck (2013:7). The debate surrounding the inclusion of these two words continues to be a popula topic in scholarly discussion. A comprehensive bibliography on the debate is offere by Wasserman (2011). Although the external evidence may, at best, lean towards the inclusion of the 'Son of God', the internal evidence seems more absolute. Both Gundry (1993:39) and Wasserman (2011:23) refer to Rudolf Schnackenburg's assessment that the anarthrous nature of Mark 1:1 and Mark 15:39 favour the longer reading (Schnackenburg 1973:321-323). Another layer of internal evidence in favour of the longer reading is that, for Mark, 'Son of God' is the most commonly used title for Jesus, much more so than 'Christ' (see Stein 2008:41; Wassermann 2011:42; Witherington 2001:70). Van lersel comments that whether or not 'Son of God' was original is immaterial since, as soon as one turns the page, the voice from heaven proclaims Jesus as the 'son' anyway (Van lersel 1998:91). His point is well taken and, in a similar vein, Gundry notes that the proclamation from heaven at the baptism "provides a much less closely matching inclusion with "Son of God" in 15:39' (Gundry 1993:39). Hooker concludes, 'the phrase is keeping with Mark's own 15:39 (Gundry 1993:39). Hooker concludes, the phrase is keeping with Mark's own belief, and forms an appropriate heading to his book' (Hooker 1991:34). Additionally, present form ... it undergirds the whole gospel' (Mann 1986:105).

6.The role of point of view in Mark is examined by Peterson (1978). In the end, he argues that the narrative world of Mark is a significant literary creation and that interpretation of Mark must keep this in mind. tradition that Jesus stands in), then has John 'tell' (Mk 1:8), then, finally, heightens the drama and has God 'tell' Jesus and, in extension, the reader, that Jesus is the Son of God. In this encounter, the omniscience of the narrator is transferred to the audience by the way of privileged information. No characters hear this pronouncement, but the narrator has made it available to the reader.

Because God himself endorses Jesus or, to put it another way, because God's point of view is the one adopted by the narrator's (or vice versa), the reader's mind is settled; if the omniscient narrator, the Old Testament, John the Baptist and God himself understand Jesus to be the Son of God, then, 'truly this man is the Son of God!' The point of view being presented by Mark is the point of view of his narrative as a whole. He works extensively to ensure that the model characters in the story adopt this view and seeks to influence his audience to do the same.

As the narrative continues, the witnesses begin to come forward. At the baptism, the reader is given an assessment of the claims that Mark has made about Jesus (that he is the Son of God; Mk $1: 1)$. The assessment that the reader is given is an unwavering endorsement; the voice from heaven proclaims, 'this is my beloved Son' (Mk 1:11). The theme of allegiance, then, is introduced in Mark 1:1, and adopted by God in Mark 1:11. This theme, broadly speaking, entails the adoption of the perspective being presented by the omniscient narrator. He is a trustworthy narrator. It is implicitly communicated that to adopt his view on the life and ministry of Jesus is the 'right view'. So how does Mark ensure that his point of view is accepted by the implied reader? By using God himself as a 'witness' to the claims of Mark 1:1, the question of point of view surrounding this first pillar in Mark is explained by Kingsbury (1983):

One thing Mark does not do: he does not deal with God in the same manner in which he deals with other characters of his story.... Mark does not permit the reader to imagine that he has 'unmediated access' either to heaven - God's abode (11:25) - or to his 'mind'. (p. 48)

This does not mean, according to Kingsbury, that Mark is unintentional about demonstrating God's point of view. So how does Mark do this? Kingsbury explains that it occurs in two ways:

Instead, Mark's procedure for incorporating God's evaluative point of view into his story is a dual one. Primarily, Mark colours his story with reference of quotations to the OT. In so doing, however, he shows that he is concerned, not just that God's evaluative point of view should be represented in his story, but that it should be afforded normative status.... For another thing, Mark, twice, has God enter the world story as an 'actor' in order to address other characters directly, and both times God speaks words drawn from the OT. (Kingsbury 1983:48)

It is worth noting, that for the human characters in the story, Mark 1:11 and God's evaluative point of view is entirely missed. ${ }^{7}$ It is only to the reader that God's point of view of Jesus is revealed. This act serves to encourage the motif of allegiance to the readers. If the omniscient, trustworthy 
narrator adopts a point of view, and indicates through Old Testament quotations that it is a consistent point of view with Scripture, and has God appear in the narrative to bolster and reaffirm this point of view, there seems little doubt that the implied reader is invited to affirm and agree. Thus, the entire first scene, Mark 1:1 to 1:11, is used by Mark to initiate the motif of allegiance in the narrative he is about to unfold. In so doing, he ensures that any reasonable reader - his implied reader - adopts the same point of view for which he is advocating. Mark has accomplished all this by creating a coherent testimony about Jesus' identity. The witnesses that he presents culminate in a forceful case that invites the reader to adopt his point of view. The witnesses are:

- The omniscient narrator (Level 1 - as omniscient narrator, he controls the world which he creates)

- God himself (Level 2 - God as God functions as the highest level of authority of any characters in the narrative world)

- Jesus himself (Level 3 - Jesus, as the Son of God, embraces this point of view of his identity)

- Cosmic evil spiritual forces (Level 4 - although evil, these forces undoubtedly possess a high level of spiritual insight and ability. They shrink back in fear and affirm that Jesus is the Son of God)

- The characters in the story (Level 5 - the one closest to the death of Jesus, and one who stood in direct opposition, affirms that Jesus truly is the Son of God).

What the omniscient narrator offers in Mark 1:1 (that Jesus is the Son of God), is reinforced by God in Mark 1:11 and Mark 9:7. Kingsbury (1989:34) succinctly notes: 'Since God in Mark's story is the supreme ruler of the universe and all history, the reader recognises that God's understanding of Jesus is normative'. The narrator presents Jesus as embracing this as well (Mk 12:1-9) and, in addition to Jesus' acceptance of his divine sonship, he seeks Old Testament justification for his actions and authority (Myers 2008:96). ${ }^{8}$ The evil spirits reiterate that Jesus is the Son of God (Mk 3:11;5:7), and finally, it is asserted by a Roman centurion (Mk 15:39). With the themes of allegiance, opposition and misunderstanding, Mark leads his readers to the conclusion that only in Jesus' death can he be understood for who he is: the Son of God. But, in addition to doing this sequentially, he also presented his case by demonstrating a progression in the level of authority of his 'witnesses'.

There are three distinct plains on which the motifs under consideration take their stand. Mark 1:11-8:26 introduces these themes and gives glimpses at what is to come. The next plain, Mark 8:27-14:53 demonstrates an increase and

8.Some examples of this appeal to the Old Testament by Jesus that Myers notes include Mark 2:24-3:1; 10:2-19; 11:7, and Mark 12:24-27 (see Myers 2008:96).

9.Closely related to the title 'Son of God' is the title 'Son of Man'. 'Son of Man' is found in Mark 2:10, 28; 8:31, 38; 9:9, 12, 31; 10:33, 45; 13:26; and 14:21, 41, 62. The scholarly debate and dil 9 : scholarly debate and dialogue about what exactly the title "Son of Man' mean shows no sign of waning. Illustrative of recent scholarship on the issue, se Bauckham (1985:23-33), Hooker (2013:651-652), Kim (1983), Leim (2013:213232), and Moloney (2013.719-738). For a classic treatment, see Perrin (1968). Morna Hooker (1967:19) contents that entwined with the concept of 'Son of Man' is the idea of authority. The link to Daniel 7:13-14 make Hooker's point convincing. escalation of the three themes discussed. Yet, it is only in the final scene (Mk 14:53-15:39) where the reader finds the express and complete presentation and implication of these three motifs come to light.

\section{Allegiance, opposition, and misunderstanding in Mark Mark 1:11 - 8:26: Allegiance, opposition,
and misunderstanding begin}

The motif of allegiance - the adoption of the implied author's point of view - begins with the first scene, but does not go unchallenged. In the next few paragraphs, Mark introduces, and then develops, the motif of misunderstanding. What is interesting is that the first question about Jesus' identity ('What is this? A new teaching and with authority'; Mk 1:27), actually enhances and propels the claims of the narrator in Mark 1:1. Mark uses the confusion of the crowd to unite the motif of misunderstanding and allegiance. After reading these words, the implied reader no doubt expects that the revelation will not be long in coming. Surely, all that it means for Jesus to be the Son of God may take a while for the crowds to grasp and, at this point, their question seems likely to be answered in short order. There is no animosity in these words, just a natural response to the revelation of the Son of God. Kingsbury explains: 'Given the widespread activity and fame of Jesus, one is tempted to think that his identity would be a secret to no one. The opposite, however, is the case' (Kingsbury 1989:37). Despite what the implied reader has been made aware of, the characters in the story are presented as being unclear about who exactly Jesus is. This is the first glimpse of the theme of misunderstanding in Mark. ${ }^{10}$

As Jesus' ministry continues, his fame begins to spread (Mk $1: 45 ; 2: 2,12,15)$. Yet, even in this exciting time of revelation, there are signs of trouble brewing. The first hint of this occurs in Mark 2:6-8. In these verses, Mark has the scribes offer the first negative assessment of Jesus' work and, thus, of his person. The charge that they level against Jesus because he heals and then forgives a man his sins is 'blasphemy' (Mk 2:7). The rhetorical question that they ask in response to Jesus' actions and words is: 'Who can forgive sins but God himself'. The implied reader, who is already privy to Jesus' divine sonship, and understands that Jesus stands in Old Testament prophetic tradition, and has been endorsed by God, would likely reply: 'Well the Son of God can forgive sins!' A Trinitarian theology is not necessary to grant that Jesus has 'authority' to do this. ${ }^{11} \mathrm{He}$ is the Son of God (Mk 1:1) and his ministry is the 'beginning of the gospel'. The first time that 'scribes' were mentioned was in Mark 1:22 where the crowd contrasts the authority of Jesus with that of the scribes. This, although not explicitly a negative assessment of the entire group, does serve to point the reader forward to the numerous times that the two parties - Jesus and the scribes

10.In Mark there are a number of questions that directly pertain to the identity of Jesus. These are examined from a literary standpoint by Kingsbury (1989:39-42).

11.See note 9 above for a brief treatment of the relationship of 'Son of Man' and 'authority'. 
(or religious leaders) - are not only contrasted by the crowds but are also engaging in direct conflict. ${ }^{12}$

The second time that the scribes are mentioned is in Mark 2:6-8. Mark 2:6 has the scribes 'questioning in their hearts'. Mark has two options for character development: he can 'show' his readers something about the characters, or he can 'tell'. He uses his position of omniscient narrator to delve into the hearts and thinking of the group and presents the readers with an overall negative assessment of the scribes. In fact, Mark is so deliberate here that he actually quotes, verbatim, what is occurring in the hearts of the scribes. He gives voice, in the form of a quotation, to what is going on inside the minds of the scribes. The inner dialogue is such that it arrives at charging Jesus with blasphemy. The trajectory of opposition begins in a rather subtle and internal fashion, but this soon begins to escalate until, in the end, Jesus is directly confronted by the religious leaders in a place of their choosing and under their leadership (Mk 14:53). ${ }^{13}$ It is here that the motif of opposition can first be noted. The motif of opposition can be defined as that viewpoint a character exhibits that conflicts with the point of view being offered by the narrator. Going even further, to be on 'God's side' one has to be on 'Jesus' side', since the narrator is on Jesus' side!

Additionally, it is here in Mark 2:6-10 that we see that the motif of misunderstanding and wonderment continue to be refined. Mark records that the crowds, at this point, 'glorify God' (Mk 2:12). They are giving their homage and allegiance to the character that authoritatively endorsed Jesus in Mark 1:11. The narrator uses this little aside to 'show' that the crowds, although not entirely clear about who Jesus is, are still open to being swayed, in some sense, to the desired point of view that Mark presents. They have not yet, clearly, arrived at a place of opposition or allegiance; they have yet to grasp the truth about Jesus' identity of which the reader is assured.

When Jesus calls Levi and enters his house, he is surrounded by 'tax collectors and sinners' (Mk 2:13-17). Here, again, opposition ensues. The scribes 'of the Pharisees' ( $\gamma \rho \mu \mu \mu \alpha \tau \varepsilon i \bar{\varsigma}$

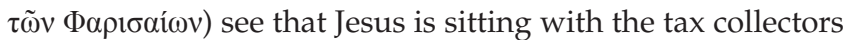
and sinners and are not able to understand. They ask Jesus' disciples why this is so, but Jesus hears it and responds to them with a rebuke. Yet, again, the motif of opposition continues to grow. In short order, the proverbial lines in the sand are drawn and the opposition to Jesus becomes vehement.

In the next section, after being questioned about fasting and responding with a proverb about wineskins, and after being accused of breaking the Sabbath, the Pharisees seek to trap Jesus. In the opening verses of Mark 3, Jesus enters a synagogue on the Sabbath. Mark tells the reader that the Pharisees are 'watching Jesus, to see whether he would heal

12. A detailed assessment of the religious leaders in Mark is offered by Malbon (2000:131-165). In her chapter on the characterization of this group, she primarily builds on the work, Mark's treatment of the Jewish leaders, by Cook (1978).

13.The role of these conflicts and their progression in directness and intensity is examined by Kingsbury (1989:65-75). on the Sabbath, so that they might accuse him' (Mk 3:2). Their opposition to Jesus has reached such a level that they are apparently only interested in accusing him. ${ }^{14}$ In yet another instance, the narrator gives the reader privileged information about the motivations and intents of the religious leaders. They are presented as being in direct opposition to Jesus. They have moved, as it were, from misunderstanding and ambivalence to outright opposition. They have adopted a point of view contrary to that of the implied author, and thus are expected to be received by the reader as being on the 'wrong side'. But it is not merely dissatisfaction or annoyance that the Pharisees betray; it is murderous intent that they show. The Pharisees go out and 'immediately' conspire with the Herodians to 'destroy Jesus' (Mk 3:6). While Jesus 'has come to destroy' ( $\dot{\alpha} \pi \nu \lambda \dot{\varepsilon} \sigma \alpha \iota)$ the evil spiritual beings that plague the people $(\mathrm{Mk1:24)}$, the Pharisees are set on 'destroying' ( $\dot{\alpha} \mathrm{0} \lambda \dot{\varepsilon} \sigma \omega \sigma \mathrm{v})$ Jesus (Mk 3:6). The irony here is striking; what Jesus is doing against evil, the Pharisees are doing against the Son of God.

It appears that Mark is using the device in contrast to illustrate something significant here. In Mark 3:1-6 the religious leaders, who one would accept as having God's point of view for their own, are seen to be acting in direct opposition to Jesus. They are blinded and, yet, the demonic beings understand and recognise Jesus for who he is (Mk $3: 11$ ). As soon as the narrative of the healing in the synagogue occurs, Mark has Jesus withdraw with his disciples and offers the aside that 'whenever the unclean spirits saw him, they fell down before him and cried out, "You are the Son of God"' (Mk 3:11). This narrative summary serves to contrast and draw attention to the level of opposition that the Pharisees are acting out. What the Pharisees miss, the unclean spirits confess. The parallels are worth noting as well: in Mark 3:1-6, Jesus heals and the Pharisees want to destroy him; in Mark 3:11 Jesus heals and the demons confess him Son of God.

In Mark's narrative, there exists a tension between the motifs of misunderstanding and opposition. For example, in Mark $3: 20$, those who misunderstand (or fail to grasp) who Jesus is (in this case his 'family') are susceptible to functioning like those in opposition. Mark's implicit point is that it is not simply direct, outright opposition that is dangerous and can alienate oneself from the desired point of view; it can also be misunderstanding when it is allowed to develop unchecked. The accusation that they level at Jesus is 'He is out of his mind'. Clearly, they are not viewed as directly opposing Jesus, but they are still indirectly functioning as such. Here, we see an important nuance to the motif of misunderstanding: It is not enough to be close to the proper point of view; one can inadvertently act in opposition when they misunderstand who Jesus is.

The next time that the theme of opposition occurs, it is especially sharp. In Mark 3:22-29 the charge levelled against Jesus is that 'Beelzebub' possesses him and that he 'casts out demons by the prince of demons'. Jesus' response about growing animosity from the Pharisees and religious leaders (see Mk 15:3, 4). 
'unpardonable sins' is cryptic, but the general thrust is clear; they are clearly standing in direct opposition. Even here, nuances in the text abound. The Pharisees claim that Jesus is casting out demons by the power of the prince of demons. In effect, they are claiming that Jesus is on the 'other side' in opposition to God. Jesus, however, explains that, in reality, sins are forgiven, except the sin of blasphemy against the Holy Spirit. Jesus' point is that they are on the wrong side; they are against him and, since God is with him, they are against God. They levelled the charge of blasphemy against him in Mark 2:7. Here, at least, it appears he is levelling the same charge at them (Mk 3:29).

Just after the reader is informed that a plot is afoot, and that the Pharisees and Herodians are conspiring against Jesus, Mark has the selection of the Twelve. At first read, knowing that two powerful groups are conspiring against Jesus, it seems a bit daunting. Although he is the 'Son of God', the odds are not fair - two groups against one individual. The reader, then, is pleased to see the tables being turned and Jesus gathering a group around him (Mk 3:13-19). Jesus 'appoints' these individuals so that they can be 'sent out and have authority to preach and cast out demons' (Mk 3:14). He is gathering a group around himself that are like him. Jesus teaches about the kingdom of God (Mk 1:14, 22) and so his disciples are called to 'preach' (Mk 3:14). He casts out demons (Mk 1:24; 3:11), and so his disciples will do the same. The reader is glad to see Jesus having support, glad, that is, until the final name in the list is read: 'Judas Iscariot, who betrayed him' (Mk 3:19). It is a surprise, narratively speaking, to the reader. This group is assumed to act in allegiance to Jesus, yet, one of their own, at some point in the narrative, will 'betray' him and, apparently, act in direct opposition to Jesus. ${ }^{15}$

As the narrative progresses, the motif of opposition continues to be found. In Mark 5:17 the people from the region of Gerasenes request that Jesus leave their region. They, much like Jesus' family in Mark 3:20, 21 are not operating out of outright opposition, but indirectly, through their misunderstanding, are still siding with those in opposition.

The motif of misunderstanding and confusion, which can be defined by ambiguity or lack of clarity about Jesus' identity, comes to the forefront of the narrative in Mark 6:1-6. The crowds express a high degree of confusion about who Jesus is. They know his parents, his occupation, his family, and, yet, they are unable to come to a clear grasp about who he is. In a number of instances, negative evaluations about peoples' understanding or response to Jesus are found in the text (Mk 6:6, 52; 7:5-7, 10, 18, 8:12, 17, 21). Some of these are authorial asides and some are found coming from Jesus.

\section{Mark 8:27 - 14:53: Allegiance, opposition and misunderstanding become outright}

Some resolution occurs at the midpoint of the narrative regarding the motif of misunderstanding (Mk 8:27-30). As

15.The characterisation of Judas in Mark is examined elsewhere by MacDonald (2013). soon as Peter makes his confession about Jesus being the Messiah, Mark returns to the motif of opposition again in dramatic fashion. In Mark 8:32-33, Jesus tells his disciples that the opposition against him has reached such a fevered pitch that it will end in his demise. Mark addresses questions that his audience may have by giving a voice to his implied reader through Peter's words and, in essence, rebukes Jesus. The reader knows that Jesus is the Son of God; how, then, can he be murdered? Peter is wondering the same thing and questions Jesus.

Jesus' response further demonstrates just how central the motifs of allegiance, opposition and misunderstanding are for Mark. Jesus rebukes Peter in light of his rebuke, and says emphatically, 'Get behind me, Satan. For you are not setting your mind on the things of God, but on the things of man' (Mk 8:33). Here, Mark, through Jesus' words, explains that the question about allegiance is more complex than one may have thought. Within Jesus' prediction is a cryptic point about his being raised ( $\mathrm{Mk} 8: 31$ ). This seems to indicate that the story of 'good news' is not bound up in just avoiding the death of the protagonist. Jesus goes even further and, in his rebuke of Peter, explains, to continue the metaphor, that to be on 'God's side' or to operate out of allegiance may look different than originally thought. Amazingly, Peter's desire to protect or stop the murder of Jesus from occurring is taken for acting in opposition to God's agenda and sides him with the enemy, Satan! The theme of allegiance, then, is not found in thinking along the lines of the 'things of men' but on the 'things of God' who works in ways that, at this point in the narrative, no characters, and likely, no implied reader can yet understand. To be in allegiance to Jesus means to properly understand the impending death of Jesus from the point of view of God. ${ }^{16}$

After predicting his death, Jesus teaches on the nature of discipleship and the necessity of 'denying himself' (Mk 8:34-38). The argument that Jesus makes, quiet clearly, is that to be in allegiance to Jesus means being in opposition to this 'adulterous and sinful generation'. In fact, 'gaining the world' means standing in opposition to Jesus or, rather, to have Jesus standing in opposition to them ('of him will the Son of Man be ashamed'; Mk 8:28).

In Mark 9:2 Jesus takes with him to the 'mountain' the inner circle of his disciples. He takes with him those who are supposed to be in allegiance to him. While on the mountain, he is transfigured and a number of cosmic events ensue. Again, Elijah is mentioned, along with a supernatural event in the heavens ('clouds'), and a voice from heaven proclaims, 'This is my beloved Son; listen to him' (Mk 9:7). In this scene, the character of God affirms to the reader what was revealed in Mark 1:1, and this is the second time that he does so. Allegiance, as a theme, is presented here in a number of ways. First of all, the presence and acquiescence of Elijah and

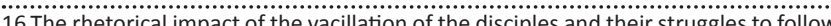
Jesus is explained by Marshall: 'Knowing that his audience would naturally identify with the disciples, and wishing to challenge them with the full demands and reality with the disciples, and wishing to challenge them with the full demands and reality
of Christian discipleship, Mark depicts following Jesus as a constant dialectic of Christian discipleship, Mark depicts following
between success and failure' (Marshall 1989:211). 
Moses demonstrate that Jesus stands in agreement and in the tradition of the most revered characters in the Old Testament. Second, as was mentioned, God himself breaks in and authoritatively commends the authority of his Son to the disciples and the reader ( $\mathrm{Mk}$ 9:7). The entire account is rich in eschatological and cosmic implications. It stands as one of the three most significant Christological points in the narrative. Mark uses the words of God from heaven to only solidify and reinforce the point of view being set forward, but also to increase the authority of Jesus because God, himself, requires that the disciple (and reader) listen to Jesus (Mk 9:7).

Here the theme of misunderstanding presents itself. It can be seen in Peter's words and in Mark's editorial clarification that the motive behind Peter's question about building tents was, 'For he did not know what to say, for they were terrified'. This does not function as an outright rebuke like Mark 8:33 did, but still is used my Mark to draw attention to the motif of misunderstanding once again, specifically the disciples.

After this, Jesus heals a boy with an unclean spirit (Mk 9:14-29). Jesus' unique authority and power are on display here because even the disciples could not cast this particular spirit out. Yet, in the wake of Jesus' act demonstrating unique power he turns to his disciples as they passed through Galilee and predicted, for the second time, that he would be betrayed and killed and raised (Mk 9:30,31). This is the second time that Jesus has spoken about his death. For the reader, who has learned that to try to prevent Jesus from this course of action (or inaction) of being killed places one squarely in opposition to Jesus and in allegiance with Satan (Mk 8:33). This second instance gives room for pause. In response to this confusing plot development, the reader likely shares the viewpoint of the disciples: 'they did not understand the saying, and were afraid to ask him' (Mk 9:32). At this point in the narrative, direct opposition has come from the religious leaders, demons, and, by way of editorial aside, Judas Iscariot. It is understood that, in some manner, these parties will conspire and will be involved in the event.

The motif of misunderstanding appears in a number of instances in the next few chapters. In Mark 10:14, Jesus rebukes his disciples because they do not understand the value and place of the children. Again, in Mark 10:17-31, Jesus interacts with the wealthy man who asks about 'eternal life'. After this, Jesus explains to his disciples that those who have wealth find it hard to enter the 'kingdom of God' (Mk 10:23). The point being made is that to be in allegiance to Jesus and act out of that reality conflicts with ambition, greed and injustice. This component of Jesus' teaching is also found in Mark 9:33-37, 42-49; 10:32, and 35-45.

After the interaction with the wealthy man, Jesus predicts his death for the third time. The third prediction is the most explicit and has the most details (Mk 10:32-34). In this instance, the motif of misunderstanding is not found after Jesus' statement, but before (Mk 10:32). Additionally, it occurs 'going up to Jerusalem', and Jesus explains his death will occur in Jerusalem. In this final prediction, Mark does not present the disciple's opinion of the evaluation of Jesus' death or their response to the notion that Jesus will die. Jesus simply offers the prediction and it is followed by silence. It is as if Mark is giving a pause for the readers to develop and formulate their own response to this revelation. The implicit question may be: What motif will the readers adopt in response to Jesus' coming death? Will they act in opposition and misunderstanding and, like Peter, try to protest? Or will they 'set their minds on things of God' (Mk 8:33)?

What Mark has done is build the case that the response to Jesus' death indicates where one stands on the spectrum of allegiance and opposition. Peter resisted the idea that Jesus would die, and was strongly rebuked (Mk 8:33), the disciples were afraid and 'do not understand' (Mk 9:32). The question hangs, how will the implied reader respond - with allegiance or with opposition?

As the narrative progresses, the opposition continues to grow and become more public and visible. In Mark 11:15-19, Jesus is presented as standing in opposition to the temple and, by extension, the religious leaders. The result of this is that 'the chief priests and the scribes heard it and were seeking for a way to destroy him' (Mk 11:18). A few sentences later, in Mark 11:27-33, the chief priests and scribes come to Jesus and ask directly, 'By what authority are you doing these things' (Mk 11:28)? The reader, who has been following the narrative, understands what the religious leaders do not; Jesus' authority comes from his being the Son of God. After all, God from heaven decrees that the characters are to 'listen to him' (Mk 9:7).

In the parable of the Tenants, the implications are significant: the religious leaders of Mark 11:27 are the wicked tenants; the 'son' that is sent is Jesus; and the landowner is God. The motif of opposition is applied here to the religious leaders again and, in this instance, they are seen to be in opposition to, not only Jesus (because they kill the son), but also to God (the landowner). The result of opposition to Jesus and God is 'destruction' (Mk 12:9). Jesus 'destroys' demons (Mk 1:24); the Pharisees want to 'destroy' Jesus (Mk 3:6; 11:18); the demonic forces attempt to 'destroy' humanity (Mk 9:22); and yet, the landowner will 'destroy' the evil tenants. The point made here is that to stand in opposition to Jesus means standing in opposition to God, which has dire consequences.

The motif of opposition is presented here again. Mark makes a point to demonstrate that it is not the words that a person or group speaks that indicates their allegiance or opposition to Jesus, it is their intentions and motives. For example, the Pharisees and Herodians call him 'Teacher', and one who 'teaches the way of God' (Mk 12:14), yet their motives are to 'destroy him' (Mk 3:6). The theme of allegiance is present only so far as it is the opposite of what is occurring. The point is that to be in allegiance to Jesus entails not only 'saying' the right things about Jesus, but also having the right motives and intentions towards him. 
The ruse continues in the account that follows (Mk 12:18-27). Instead of the Pharisees and Herodians, it is the Sadducees that approach Jesus in this instance. The events that transpire in this account are similar to one that preceded it. Mark gives the reader privileged information here again. He tells his audience, not about the intentions of the characters as he did with the Pharisees and Herodians (Mk 12:12-17), but, instead, tells his readers about the beliefs of the group antagonising Jesus. He mentions that the Sadducees 'say that there is not resurrection' (Mk 12:18). After an elaborate and complex question by the Sadducees about marriage, remarriage, death and resurrection, Jesus responds in Mark 12:24-27. Especially interesting to the reader are the words of Mark 12:26-27. Jesus explains that the dead are raised because of Scriptural precedence and common sense (God is the God of the living). This is a relief to the anxious reader because, at this point, three times Jesus has predicted his death and his 'being raised' (Mk 8:31; 9:30-32; 10:32-34). Thus, it is comforting to know that, in spite of what Jesus seems confident will occur in Jerusalem, his claim that he will 'rise again' has some manner of Old Testament precedence. In this instance, opposition to Jesus takes the form of a ruse, but also includes believing wrongly about God, the Scriptures and Jesus being 'raised'.

An interesting break with the opposition motif is found in the next encounter. In rapid succession, these encounters come at the reader. First, the Pharisees and Herodians, then the Sadducees, next, it is a scribe who comes to Jesus to ask questions. This encounter takes a different route than the others. In this account (Mk 12:28-34), no motivation or intent is given for the scribe's encounter with Jesus. All the reader is told is that the scribe notices how well Jesus had answered the others and, so, decides to ask his own. The question, 'what is the greatest commandment' is one which is answered by Jesus from Old Testament Scripture (Mk 12:29-31). The scribe rephrases Jesus' answer back to him and captures the essence and point that Jesus is making. Mark records:

And when Jesus saw that he answered wisely, he said to him, 'You are not far from the kingdom of God.' And after that no one dared to ask him any more questions. (Mk 12:34)

Up until this point in Mark's narrative, the group known as the 'scribes' have been presented in quite a negative light (i.e., Mk 2:6, 16; 3:22; 7:1, 5). Additionally, in the predictions of his death in Mark 8:31 and 10:33, the reader is told that the scribes would have a hand in Jesus' death. In this instance, where a scribe comes and, in some sense, is responded to positively by Jesus and given credit for his 'wise' answer, the motif of opposition is altered, for a time. The theme is altered by Mark and demonstrates, among other things, that one can respond positively to Jesus even if one finds themselves as a member of a group that, generally speaking, opposes Jesus. The lack of insight into this character's thinking and emotions heightens the tension of the scene. The reader expects, no doubt, another confrontation, but is presented with something else: an ambiguous encounter which leaves the door open for one to respond positively to Jesus if they are an outsider or against him (Myers 2008:317). In this account, it is worth noting that allegiance is again understood to be acting and interacting with Jesus in agreement with who he claims he is, and how Mark presents him. The scribe's words, 'You are right Teacher', capture the spirit of this theme (Mk 12:32). This will be seen to be the case throughout Mark and especially in Mark 15:39.

Just as in Mark 12:13-17, the narrator shows his readers that it is the inner thoughts and motives, and not the words or even actions, that one demonstrates that shows if one is in allegiance to Jesus, the character Jesus says the same in Mark12:38-40. Here, instead of the omniscient narrator doing the work to cast the Pharisees in opposition, it is Jesus, himself, who does so. Jesus tells the people to 'Beware of the scribes, who like to walk around in long robes and like greetings in the marketplace' (Mk 12:39). Jesus gives the characters in the story (whose names are not defined) and, by extension, the readers, a glimpse into the thinking and heart of the religious leaders. Here again, Jesus explains that the question of allegiance or opposition (to be in accordance with God's point of view or not) is not a matter of outward actions, but an inner consistency in which one's beliefs about God (and Jesus) and one's actions measure up. The cost of being found in the place of opposition to Jesus is explained as being in the place of 'greater condemnation' (Mk 12:40). The evil of opposition is demonstrated by Mark in his characterisation of Judas. The one who is closest to Jesus is seen to be 'the Betrayer' (MacDonald 2013:123).

\section{Mark 14:53 - 15:39: Allegiance, opposition and misunderstanding reach their pinnacle}

After being arrested, Jesus is brought before the council and interrogated (Mk 14:53-65). Mark records that the words of Jesus in Mark 14:26-31 are fulfilled; Peter denies Jesus (Mk 14:66-72). Mark has shown the reader that one can fail to understand who Jesus is, and, yet, even though the individual does not exhibit outright animosity, they are still functioning out of a perspective of opposition.

Discipleship is hard, even for those on the 'inside'. Yet, in Mark 14:66-72, Mark introduces a redemptive element into the misunderstanding motif. Peter acts in opposition to Jesus by denying him, but his response to his actions is one of sorrow, and all hope is not lost for Peter. Later, in Mark 16:7, Peter is mentioned by the man in the white robe at Jesus' tomb. Although both Peter and Judas act in opposition, the reader sees that Peter, although he was operating primarily out of misunderstanding, is eventually, in some sense, 'restored', or in the least, given hope for such a reversal. The final word on the character, Peter, is hope. Judas, on the other hand, does not appear in the narrative again. Jesus' damning words, about it being better for Judas to 'never have been born', rings out and is conclusive. The final word on Judas is one of judgment. All this is used by Mark to show that the intents and motives towards Jesus are the primary reality that matter. One can act in opposition, but still be given hope if a change occurs. At the same time, one can act in allegiance, 
yet, in their motives and inner dialogue, be adversaries to Jesus.

After this, Jesus is brought before Pilot, tried, and delivered to be crucified. In this sequence of events, Pilot embraces the role of one who misunderstands Jesus, and to begin with, is not entirely antagonistic to Jesus, yet, by embracing his misunderstanding, he inevitably begins functioning as one who opposes Jesus. Pilot, Mark writes, knew what the intentions of the religious leaders were, that they were doing these things out of 'envy' (Mk 15:10). Mark even goes so far as to express that Pilot was not entirely sure what the transgression was that Jesus actually committed (Mk 15:13: 'Why, what evil has he done?'). In the end, he acquiesces and, in a desire to satisfy the crowds, goes over to the realm of opposition and sentences Jesus to death.

In Mark 13:15-18, the narrator casts the religious establishment in Israel as acting in direct opposition to Jesus. In Mark 15: 16-20, the Roman authorities are casted as in opposition to Jesus. Up until this point, the Roman officials, delegates, and population have not played a significant role in the narrative. In Mark 15:16-20 the soldiers lead Jesus away, clothe him in purple, twist a crown made of thorns and place it on his head, and begin to mock him. The level of opposition, which at this point has reached fevered pitch, is startling to the reader. Next, Mark tells the reader that after taking Jesus out, they bring him to Golgotha and crucify him.

At this definitive destination, the narrative world that Mark has created is rife with tension. What began as 'the good news about Jesus Christ, God's Son' has now led to the point where that same Son of God is being executed. He is alone, abandoned, shamed and hanging on a cross. The expectation of the triumph of the Son of God has been squelched, and those advocating for opposition seem to be gaining the upper hand. While on the cross, the two robbers and people passing by continue the mocking begun earlier. One of the criticisms that is levelled at Jesus, is that he stood in opposition to the temple, even claiming that he would 'destroy it', and, yet, seems unable to save himself from his situation (Mk 15:29). The mocking continues, this time coming from the chief priests and leaders (Mk 15:30). Eventually, at the 'ninth hour' (Mk 15:34), Jesus calls out, is offered wine, expires and breathes his last breath (Mk 15:37).

For the reader, who is puzzling out how Jesus' death can be hailed as the 'good news', a series of significant events occur in the wake of Jesus' death. First of all, the curtain veil is torn. Second, a centurion who is standing near the cross, sees Jesus die and exclaims that 'this truly was the Son of God' (Mk 15:39).

The reader recognises that this is the first time in the Gospel of Mark that any human character has vocalised the truth that Jesus is the Son of God. This is the one reality that the characters in the story are unable to grasp in full. It has been affirmed by the narrator (Mk 1:1; 3:11), admitted by the evil spiritual forces (Mk 1:24; 5:7), decreed by God (Mk 1:11; 9:7), hinted at by Jesus (Mk 12:1-12; 13:32; 14:46), and, finally, is now recognised by a very unlikely human character - a Roman centurion. It must be noted that in Mark 15:39, the secret, so to speak, is finally out and it is revealed that Jesus is the Son of God.

\section{Conclusion: Opposition, misunderstanding and allegiance resolved}

This article has given its attention to an in-depth examination of the narrative contours of Mark. Mark's point of view has been studied, through the themes of opposition, misunderstanding and allegiance. In Mark 15:39 at the moment of Jesus' death, the opposition reaches its great pinnacle - all earth and supernatural forces seem to conspire against and abuse Jesus. Yet, it is also in the scene of opposition that we see one, who by all accounts, ought to have embraced the motif of opposition, switch positions and vocalise what, for the implied reader, amount to the central Christological title and the truth that remained hidden from those who followed the motif of misunderstanding. In the centurion's words 'Truly this was God's Son' (15:39), the theme of allegiance is explained and the theme of misunderstanding is resolved. Thus, two options for the reader remain: opposition or allegiance to Jesus, the Son of God.

In summation, by virtue of his development and the nuances with which he presents the themes of allegiance, opposition and misunderstanding, and, in light of the levels of authority of his witnesses, all of which affirm that Jesus is the Son of God, Mark rests his case. His initial statement in Mark 1:1, 'The beginning of the gospel of Jesus Christ, the Son of God' (ESV) is now completed. Mark, in approaching his theme from these two perspectives (developmentally through motifs and with the levels of authoritative witnesses) invites his reader to side with the 'right' point of view; with himself, God, Jesus, all spiritual forces that Jesus is the Son of God. The second, implicit initiation in this and model the actions of the centurion who switched allegiance from Caesar, son of god, to Jesus, the true Son of God, the culmination of Israel's history, who is known and revealed only in his crucifixion for the many (Mk 14:24).

\section{Acknowledgements Competing interests}

The authors declare that they have no financial or personal relationships which may have inappropriately influenced them in writing this article.

\section{Authors' contributions}

This article represents a reworked version of aspects from the PhD dissertation of D.K.M., titled Allegiance, opposition, and misunderstanding: A narrative critical approach to 'Son of God' in Mark's gospel, in the Department of New Testament Studies, University of Pretoria, with E.v.E. as supervisor. 


\section{References}

Bauckham, R., 1985, 'The Son of Man: "A man in my position" or "someone"', Journal for the Study of the New Testament 23, 23-33. http://dx.doi.org/10.1177/ 0142064 X8500702302

Booth, W.C., 1983, The rhetoric of fiction, University of Chicago Press, Chicago, IL.

Collins, A.Y., 2007, Mark: A commentary, (Hermeneia), Fortress Press, Minneapolis, MN.

Cook, M.J., 1978, Mark's treatment of the Jewish leaders, E. J. Brill, Leiden.

Ehrman, B., 1991, 'The text of Mark in the hands of the orthodox', Lutheran Quarterly $5,143-156$

Evans, C.A., 2000, 'Mark's incipit and the Priene Calendar inscription: From Jewish gospel to Greco-Roman gospel', Journal of Greco-Roman Christianity and Judaism $1,69-81$.

Fowler, R.M., 1991, Let the reader understand: Reader-response criticism and the Gospel of Mark, Fortress Press, Minneapolis, MN.

Guelich, R., 1989, Mark 1-8:26, Thomas Nelson, Nashville, TN.

Gundry, R.H., 1993, Mark: A commentary on his apology for the cross, Eerdmans, Grand Rapids, MI.

Hooker, M.D., 1967, The Son of Man in Mark, SPCK, London.

Hooker, M.D., 1991, Gospel according to St. Mark. A \& C Black, London.

Hooker, M.D., 2013, 'The expression "Son of Man" and the development of Christology: A history of interpretation', Journal of Theological Studies 64(2), 651-652.

Kim, S., 1983, The "Son of Man" as the Son of God, Institute for Biblical Research, Rome. Kingsbury, J.D., 1989, Conflict in Mark: Jesus, authorities, disciples, Fortress Press, Minneapolis, MN

Kingsbury, J.D., 1983, The Christology of Mark's Gospel, Fortress Press, Minneapolis, MN.

Leim, J.E., 2013, 'In the glory of his Father: Intertextuality and the apocalyptic Son of Man in the Gospel of Mark', Journal of Theological Interpretation 7(2), 213-232.

MacDonald, D.K., 2013, 'The characterisation of a false disciple: Judas Iscariot in Mark's Gospel', McMaster Journal of Theology and Ministry 15, 119-135.
Malbon, E.S., 2000, In the company of Jesus: Characters in Mark's Gospel, Westminster John Knox Press, Louisville, KY.

Mann, C.S., 1986, Mark: A new translation with introduction and commentary, Doubleday, New York, NY.

Marcus, J., 2000, Mark 1-8, Yale University Press, New Haven, CT.

Marshall, C.D., 1989, Faith as a theme in Mark's narrative, Cambridge University Press, New York, NY.

Moloney, F.J., 2013, 'Constructing Jesus and the Son of Man', Catholic Biblical Quarterly 75(4), 719-738.

Myers, C., 2008, Binding the strong man: A political reading of Mark's story of Jesus, Orbis Books, Maryknoll, NY.

Perrin, N., 1968, 'The Son of Man in the synoptic tradition', Biblical Research 13, 3-25.

Peterson, N.R., 1978, 'Point of view in Mark', Semeia 12, 97-121.

Resseguie, J., 2005, Narrative criticism of the New Testament: An introduction, Baker Academic, Grand Rapids, MI.

Rhoads, D., Dewey, J. \& Michie, D.M., 1999, Mark as story: An introduction to the narrative of a Gospel, Fortress Press, Minneapolis, MN.

Schnackenburg, R., 1973, “"Das Evangelium” im Versta"ndnis des altesten Evangelisten', in P. Hoffman (ed.), Orientierung an Jesus: Zur Theologie der Synoptike, pp. 309-324, Herder, Freiburg.

Schweizer, E., 1970, The good news according to Mark, Westminster John Knox Press, Louisville, KY.

Stein, R.H., 2008, Mark, Baker Academic, Grand Rapids, MI.

Van Eck, E., 2013, 'Mission, identity and ethics in Mark: Jesus, the patron for outsiders', HTS Teologiese Studies/Theological Studies 69(1), Art. \#2003, 13 pages. http:// dx.doi.org/10.4102/ hts.v69i1.2003

Van lersel, B.M., 1998, Mark: A reader-response commentary, (Journal for the Study of the New Testament. Supplement series no. 164), Sheffield Academic Press, Sheffield, UK.

Wasserman, T., 2011, 'The "Son of God" was in the beginning (Mark 1:1)', The Journal of Theological Studies 62(1), 20-50. http://dx.doi.org/10.1093/jts/flr013

Witherington, B., 2001, The Gospel of Mark: A socio-rhetorical commentary, Eerdmans, Grand Rapids, MI. 